\title{
Our Experience of Nonoperative Management in Patients with Liver Injury Due to Multiple Blunt Trauma
}

\author{
Multiple Künt Travması Olan Karaciğer Yaralanmalı \\ Hastalardaki Nonoperatif Tedavi Deneyimlerimiz
}

Mehmet Aykut Yildirim ${ }^{1}$,

Hulya Vatansev²,

Mustafa Senturk ${ }^{1}$

Cengiz Kadiyoran ${ }^{3}$,

Sinan İyisoy ${ }^{4}$,

${ }^{1}$ Necmettin Erbakan University, Meram

Faculty of Medicine, Department of General

Surgery, Konya, Turkey

${ }^{2}$ Necmettin Erbakan University, Meram

Faculty of Medicine, Department of Chest

Disease, Konya, Turkey

${ }^{3}$ Necmettin Erbakan University, Meram

Faculty of Medicine, Department of

Radiology, Konya, Turkey

${ }^{4}$ Necmettin Erbakan University, Meram

Faculty of Medicine, Deparment of Education

And Medical Informatics Konya,Turkey

Geliş Tarihi/Received: 7 October 2019

Kabul Tarihi/Accepted: 3 January 2020

Öz

Amaç: Künt multiple travma nedeniyle nonoperatif tedavi (NOT) uygulanan karaciğer travmalı hastaların takibinde halen fikir birliği yoktur. Çalışmamızda hastanemizde NOT uygulanan künt travma sonucu karaciğer yaralanması olan hastalara ait deneyimlerimizi sunmayı amaçladık.

Hastalar ve Yöntem: Calışma 2008-2014 yılları arasında hastanemize multiple travma nedeniyle bașvuran ve karaciğer yaralanması olan 104 hasta retrospektif olarak değerlendirildi. NOT başarılı olan hastalar ve NOT başarısız olup laparatomi yapılan hastalar tasnif edildi.

Bulgular: Künt karın travmasına bağlı 104 hastanın tamamında solid organ yaralanması olup bunların 58 'inde toraks travması mevcuttu. Künt karın travması nedeniyle karaciğer yaralanması olan 94 hastaya NOT başarı ile uygulandı.10 hastada konservatif takip sırasında cerrahi tedaviye dönüldü. Yaralanma derecesine göre 35 hasta grade 1,23 hasta grade 2, 24 hasta grade 3 ve 12 hasta grade 4 olarak derecelendirildi. NOT'un başarısız olduğu karaciğer travmalı 10 hastanın verileri NOT uygulanan grupla karşılaştırıldı.

Sonuç: Yaralanma derecesi yüksek veya toraks travmasının eşlik ettiği hastalarda komplikasyon gelişimi de artmaktadır. Grade 4 yaralanmalarda NOT uygulanan vakalarda komplikasyonların görülme oranı yüksektir

Anahtar Kelimeler: Künt travma, karaciğer, nonoperatif tedavi, toraks travması

\section{Abstract}

Aim: There is still no consensus on nonoperative management (NOM) for the treatment of patients with liver injury due to multiple trauma. In this study, we aimed to present our experience in patients who underwent NOM in our hospital due to liver injury resulting from blunt trauma.

Address correspondence to: Mehmet Aykut Patients and Methods: The study was evaluated retrospectively in 104 patients due to blunt multiple Yildirim, Necmettin Erbakan University, Meram Faculty of Medicine, Department of General Surgery, Konya,Turkey

e-mail: drmayildirim@hotmail.com

\section{ORCID}

Mehmet Aykut Yildirim

https://orcid.org/0000-0001-9580-6004

Hulya Vatansev

https://orcid.org/0000-0002-8382-3904

Mustafa Senturk

traumato our hospital between 2008-2014 with applied liver injuries. Patients with successful NOM and those who underwent laparotomy due to failure of NOM were grouped.

Results: All of the 104 patients had solid organ injury due to blunt abdominal trauma, and 58 of these had thorax trauma. NOM was successfully performed in 94 patients with liver injury due to blunt abdominal trauma. The treatment was converted to surgery in 10 patients during conservative follow-up. According to injury grades; 35 patients were graded as Grade 1, 23 patients as Grade 2, 24 patients as Grade 3, and 12 patients as Grade 4. Data of 10 patients with liver trauma and NOM failed were compared with those of the NOM group.

Conclusion: The development of complications increases in patients with high-grade injury or those accompanied by thorax trauma. The rate of complications is high in patients who receive NOM in Grade 4 injury.

Key words: Blunt trauma, liver, nonoperative treatment, thorax trauma

https://orcid.org/0000-0002-3230-1743

Cengiz Kadiyoran

https://orcid.org/0000-0002-7173-3530

Sinan Iyisoy

https://orcid.org/0000-0001-5895-9984

Cite this article as: Yildirim MA, Vatansev $\mathrm{H}$, Senturk M, Kadiyoran C, lyisoy S. Our Experience of Nonoperative Management in Patients with Liver Injury Due to Multiple Blunt Trauma. Selcuk Med J 2021;37(1): 57-63

“This article is licensed under a Creative Commons Attribution-NonCommercial 4.0 International License (CC BY-NC 4.0)" Disclosure: None of the authors has a financial interest in any of the
products, devices, or drugs mentioned in this article. The research was
not sponsored by an outside organization. All authors have agreed to allow
full access to the primary data and to allow the journal to review the data
if requested. 


\section{INTRODUCTION}

Thoracic trauma is also present in approximately $50 \%$ of patients presenting with multiple blunt abdominal trauma (1). Nonoperative management (NOM) application is current approach in patients with solid organ injury due to blunt abdominal trauma, and especially in patients that are hemodynamically stable and have no acute abdominal findings $(2,3)$. With the recent improvements in intensive care conditions, imaging modalities and interventional radiologic procedures, success rate of conservative approach in traumas has increased (2). Conservative treatment approaches have been developed in hemodynamically stable patients, particularly with the use of computed tomography $(\mathrm{CT})$. It is known that the rates of morbidity and mortality are lower with conservative treatment approach compared to operative treatment. However, while NOM is performed in hemodynamically stable patients with all injury grades, there is no data on treatment management and limits of follow-up process according to injury grades (4). In this study, we aimed to present our experience in patients with liver injury due to blunt trauma who were treated and followedup in our hospital, which is the center with highest number of trauma presentations in Konya province of Turkey.

\section{PATIENTS AND METHODS}

The study was performed with the approval received from Necmettin Erbakan University Meram Faculty of Medicine, Non-interventional Clinical Trials Ethics Committee (Decision No: 2012/156). The study was evaluated retrospectively in 104 patients due to blunt multiple trauma to our hospital between 2008-2014 with applied liver injuries. Patients who received NOM were selected according to being hemodynamically stable (including those who were stable after the first resuscitation) and having no findings of peritoneal irritation. NOM failed in 10 patients and laparotomy was performed in these patients. Our criteria for laparotomy were unstable hemodynamics despite adequate resuscitation and presence of peritoneal irritation findings. Patients with successful NOM and those who underwent laparotomy due to failure of NOM were grouped. Our patients were graded according to the American Trauma Society Liver Injury Scoring System. Patients' demographic data, mechanism of trauma, presence of additional trauma, hemodynamics status at presentation, injury grade on CT, need for blood and blood products during hospitalization, need for laparotomy, duration of hospitalization, need for intensive care, laboratory values at first admission including hemoglobin, hematocrit, leukocyte count, alanine aminotransferase (ALT), aspartate aminotransferase (AST), alkaline phosphatase, gamma-glutamyl transferase, determination of oral feeding time, Glasgow Coma Scale, injury severity score and presence of additional trauma were recorded and evaluated.

After abdominal examination, patients underwent Focused Assessment Sonography for Trauma (FAST) in the emergency department. Patients with thorax trauma were followed up together with the thoracic diseases clinic. All patients were evaluated with CT during first diagnosis stage. Patients who received NOM were closely followed-up after the first assessment. Patients with a trauma in addition to thorax trauma were directly admitted to and monitorized in the intensive care unit. Abdominal examination, hemogram and liver function tests were performed at the hours 0, 1, 6 and 24 after the hospitalization. Patients who required continuous fluid resuscitation were evaluated by the department of interventional radiology for transarterial embolization(TAE). Patients with failed procedure or those evaluated as ineligible and patients who developed findings of peritoneal irritation were excluded from the conservative treatment group and taken to operation. Oral feeding was initiated at the end of the 24th hour in the patients who were hemodynamically stable and had a normal abdominal examination. Hemogram and liver function tests were performed once a day. Patients with normal vital findings and physical examination were discharged.

Bed rest was recommended for 2 weeks in patients with Grade 1, 3 weeks in patients with Grades 2 and 3 , and at least 6 weeks in patients with Grade 4. Outpatient clinic controls were performed 3 days after the discharge. Patients with respiratory complaints at follow up were evaluated by thoracic diseases clinic. Vital findings were evaluated and recorded. In addition, all patients were called for controls in the 1st, 3rd and 6th months, and evaluated with anamnesis and physical examination. Patients with complaints during these evaluations were investigated.

\section{Statistical Analysis}

Data obtained in the study was analyzed using SPSS (Statistical Package for Social Sciences) for Windows v. 21 statistical software. Kruskal-Wallis, Chi-square, Mann-Whitney $U$ and Tukey HSD tests were used for the confirmation. Differences between the groups according to the data obtained were 
Table 1. American Trauma Society Liver Injury Scoring System

\begin{tabular}{|c|c|c|}
\hline GRADE & Hematoma & Laseration \\
\hline 1 & $\begin{array}{l}\text { Subcapsular, not increasing, lower than } \\
10 \% \text { of surface area }\end{array}$ & $\begin{array}{l}\text { Capsular rupture, not bleeding, parenchymal } \\
\text { depth less than } 1 \mathrm{~cm}\end{array}$ \\
\hline 2 & $\begin{array}{l}\text { Subcapsular, not increasing, } \\
10-50 \% \text { of surface area }\end{array}$ & $\begin{array}{l}\text { Capsular rupture, active bleeding, parenchymal } \\
\text { depth } 1-3 \mathrm{~cm} \text {, length }<10 \mathrm{~cm}\end{array}$ \\
\hline 3 & $\begin{array}{l}\text { Subcapsular, higher than } 50 \% \\
\text { of surface area or increasing } \\
\text { Active bleeding subcapsular hematoma } \\
\text { rupture, hematoma greater than } 2 \mathrm{~cm} \text { or } \\
\text { growing intraparenchymal hematoma }\end{array}$ & parenchymal depth higher than $3 \mathrm{~cm}$ \\
\hline 4 & $\begin{array}{l}\text { Active bleeding ruptured } \\
\text { intraparenchymal hematoma }\end{array}$ & $\begin{array}{l}\text { Parenchymal damage involving } \\
25-50 \% \text { of liver lobe }\end{array}$ \\
\hline 5 & $\begin{array}{l}\text { Juxta hepatic vein injuries such } \\
\text { as vascular retrohepatic vena cava } \\
\text { or common hepatic veinsı }\end{array}$ & $\begin{array}{l}\text { Parenchymal damage involving } \\
>50 \% \text { of liver lobe }\end{array}$ \\
\hline 6 & Hepatic avulsion & \\
\hline
\end{tabular}

tabulated. $p<0.05$ values were considered statistically significant.

\section{RESULTS}

A total of 104 patients with liver injury due to blunt abdominal trauma were evaluated. NOM was successfully performed in 94 patients. Conservative treatment was left and surgical exploration was performed in 10 patients who received NOM. According to injury grades; 35 patients were graded as Grade 1, 23 patients as Grade 2, 24 patients as Grade 3 , and 12 patients as Grade 4. Data of 10 patients with liver trauma and NOM failed were compared with those of the NOT group. The mean age was 31.04 years in patients who received NOM and 27.90 years in patients with failed NOM. The mean age was higher in the patients who received NOM ( $p>0.05)$. When patients were evaluated in terms of gender; 26 $(27.7 \%)$ of patients with liver trauma who received NOM was female and $68(72.3 \%)$ were male. Of the patient with failed NOM, $1(10 \%)$ was female and 9 $(90 \%)$ were male. Most patients were male in both groups $(p>0.05)$ (Table 2$)$.

When patients successfully treated with NOM were

Table 2. Comparison of patients with liver trauma who received NOM and those with failed NOM.

\begin{tabular}{|c|c|c|c|}
\hline Parameters & Not $n=94$ & Not Failed $n=10$ & $\mathbf{P}$ \\
\hline Mean age & 31.04 & 27.90 & $p>0.05$ \\
\hline \multirow[t]{4}{*}{ Gender } & M & $\mathrm{M}$ & $p>0.05$ \\
\hline & $72.3 \%$ & $90 \%$ & \\
\hline & & & \\
\hline & $27.7 \%$ & $10 \%$ & \\
\hline \multicolumn{4}{|l|}{ Hemodynamics } \\
\hline \multirow[t]{2}{*}{ Status (first evaluation) } & Stable & Stable & $p<0.05$ \\
\hline & $95.7 \%$ & $80 \%$ & \\
\hline $\mathrm{BP} \mathrm{mmHg}$ & $118 \mathrm{mmHg}$ & $108.4 \mathrm{mmHg}$ & $p<0.05$ \\
\hline Pulse/min & $83 / \mathrm{dk}$ & $94,4 / \mathrm{dk}$ & $p<0.05$ \\
\hline GCS(median) & 14 & 12 & $P<0.05$ \\
\hline ISS(median) & 22 & 36 & \\
\hline Hemoglobin(g/dL) & 12.8 & 12.06 & $p>0.05$ \\
\hline Hematocrit ( \%) & 38.28 & 34.8 & $p>0.05$ \\
\hline Leukocytes $\left(\mathrm{K} / \mathrm{mm}^{3}\right)$ & 12.9 & 18.45 & $p<0.05$ \\
\hline Amount of Blood transfusion(U) & 0.61 & 2.2 & $p<0.05$ \\
\hline Length of stay in intensive care unit (days) & 0.96 & 6.30 & $p<0.05$ \\
\hline Total length of stay in hospital (days) & 4.05 & 13 & $p<0.05$ \\
\hline AST U/L & $142.3(20-424)$ & $174.6(38-566)$ & $P>0.05$ \\
\hline ALT U/L & $138.5(35-448)$ & 210.6 & \\
\hline T.Bilurubine $\mathrm{g} / \mathrm{dl}$ & $1,1(1-1,4)$ & $2,13(0,9-5,5)$ & $P<0,05$ \\
\hline
\end{tabular}


evaluated according to the mechanisms of liver trauma; pedestrian injury $(\mathrm{PI})$ was found as the mechanism of trauma in $4(4.3 \%)$ patients, motor vehicle accident (MVA) in $57(60.6 \%)$ patients, motorcycle accident in $21(22.2 \%)$ patients, and falling from height in 12 $(12.8 \%)$ patients. When the mechanisms of trauma were evaluated in patients with failed NOM; PI was found in $3(30 \%)$ patients, MVA in $4(40 \%)$ patients, and motor vehicle accident in $3(30 \%)$ patients. The most common mechanism of trauma was MVA $(p<0.05)$ (Table 2). In addition to liver trauma, extra-abdominal traumas included thorax trauma in 58 (55.7\%) patients, extremity trauma in $7(6.7 \%)$ patients, and head trauma in $11(10.5 \%)$ patients. In addition to liver trauma, retroperitoneal hematoma was found in $2(1.9 \%)$ patients, and spleen injury in $11(11.7 \%)$ patients (highest Grade 2). Among the patients with failed NOM; additional spleen trauma was found in 2 (20\%) patients (highest Grade 2), and retroperitoneal hematoma in $3(30 \%)$ patients. In addition to abdominal traumas, extra-abdominal traumas included thorax in $5(50 \%)$ patients, extremity trauma in 1 (10) patient, and head trauma in $1(10 \%)$ patient in this group. The most common trauma in addition to liver trauma was found as thorax trauma in patients who received NOM. Among the thorax traumas, the most common trauma was pneumothorax followed by rib fracture $(p>0.05)$.

In the hemodynamics evaluation during the first presentation, patients who received NOM were hemodynamically more stable than those with failed NOT $(p<0.05)$. Glasgow Coma Scale (GCS) scores were higher in NOM patients compared to the patients with failed NOM. Injury severity score (ISS) and the rate of blood transfusion were lower in the patients who received NOM. The mean lengths of stay in hospital and in the intensive care unit were found as 0.96 and 4.05 , respectively, in patients with liver trauma who received NOM. The mean lengths of stay in hospital and in the intensive care unit were found as 6.30 and 13 days, respectively, in patients with failed NOM. Six $(60 \%)$ of the patients with failed NOM were operated due to peritoneal irritation findings, and $4(40 \%)$ due to hemodynamic instability. Active bleeding was observed in 3 of the patients operated due to hemodynamic instability. Injury grade based on CT was operatively higher in these patients. It was found in one patient that bleeding was stopped and hemodynamic instability was developed due to insufficient resuscitation. Injury grade was operatively found as Grade 4 in all these patients. Homeostasis

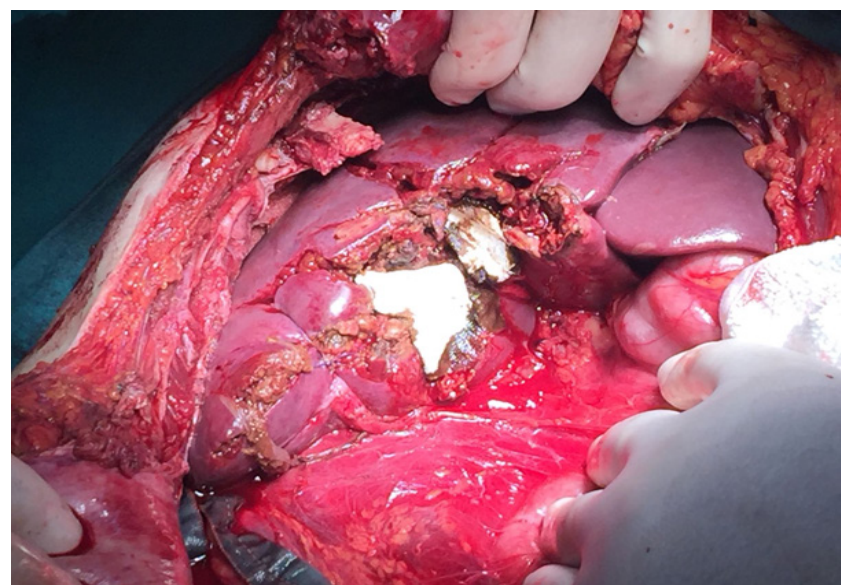

Figure 1. Intraoperative imaging active bleeding from liver

was achieved with packing in 3 patients with active bleeding (Figure 1). Biliary peritonitis was found in 3 of the 6 patients with peritoneal irritation findings who underwent laparotomy. In addition to peritoneal irritation findings, among laboratory outcomes total bilirubin and direct bilirubin values were increased, but hemoglobin and hematocrit values were not significantly decreased in these three patients. Among the remaining three patients, right colon perforation was observed in two patients and jejunum perforation in one patient.

Complications were observed in $4(4.25 \%)$ of the patient who received NOM, before discharge. One patient with bilioma and biliary leak was

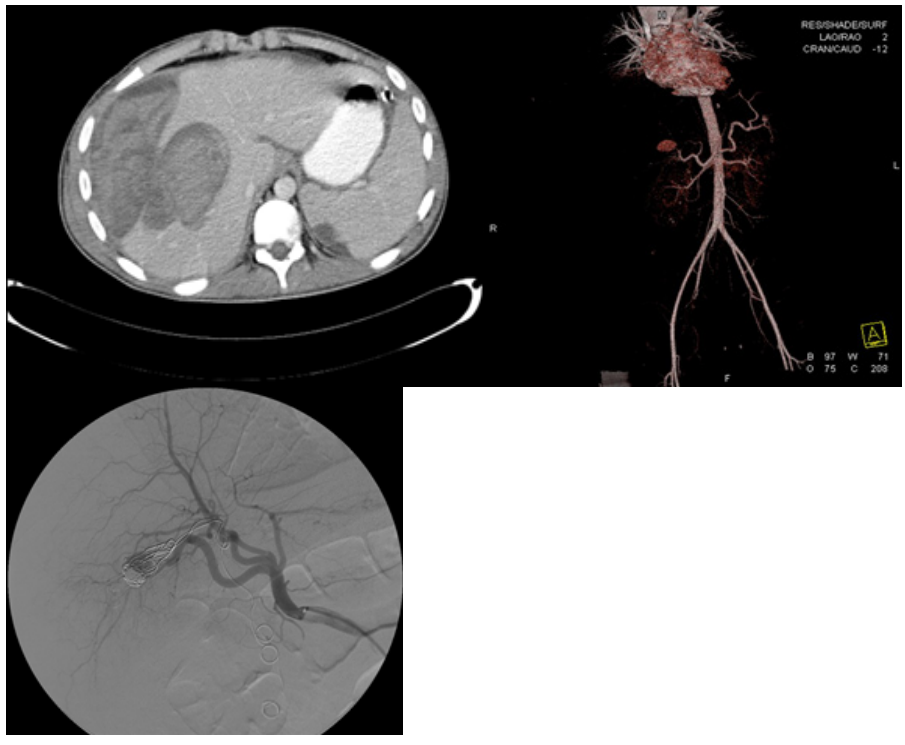

Figure 2. Grade 4 liver trauma TAE figures. 
treated with percutaneous drainage + ERCPstent and antibiotherapy, and the other patient who developed liver abscess with percutaneous drainage + antibiotherapy. Liver injury grade was found as Grade 3 and Grade 4 in these complicated patients. Hemobilia and melena was applied 2 patients with TAE. There was no postoperative complication after TAE (Figure 2). None of the patients with failed NOM developed complication .

\section{DISCUSSSION}

Although there are no clear data about the relationship between liver injury grade and NOT failure, it has been underlined that hemodynamics status is important rather injury grade (5-8). Hemodynamic instability accounts for $75 \%$ of NOM failure. Delayed bleeding seen between $2.8 \%$ and $3.5 \%$ is still reported as the most important cause of mortality (9). Emergency surgical approach has been replaced by hepatic angioembolization in some centers. However, herein experience of the center, emergency conditions, and availability of a radiologist who can perform vascular interventions affect practicability of the procedure (10). In our study, angioembolization was performed to stop GIS bleeding developed in two patients followed up with NOM (Figure 2). The reasons for our decision of surgery in patients with failed NOM were hemodynamic instability and peritoneal irritation findings. Transarterial embolization was a treatment method, which we preferred according to general status of hemodynamically unstable patients. Angiographic embolization was not considered because of the general status of the patients who underwent surgery. We believe that inadequate resuscitation was one of the reasons of impaired hemodynamics in our patients with bleeding stopped.

In blunt trauma related organ injuries, NOM is recommended in hemodynamically stable patients without peritoneal irritation findings in centers with facilities of serial physical examination, hemoglobinhematocrit monitorization and emergency laparotomy $(11,12)$. Although it has been reported in the literature that hemoglobin and hematocrit measurements should be made at hours $0,6,8$ and 24 from the first admission, there is no clear approach for frequency of hemoglobin-hematocrit measurement, frequency of physical examination, need for intensive care, time of beginning to oral intake and duration of resting in the forthcoming periods (3). In our study, hemoglobin and hematocrit values of the patients who received NOM were made at the hours $0,1,6$ and 24 . These values were measured once a day within the other days. We believe that measurements with this frequency are ideal. We recommend to perform physical examination at the hours $0,1,6,12$ and 24 within the first 24 hours and twice a day in the following days. Oral foods were given from the 24th hour in hemodynamically stable patients with normal mental status and abdominal examination. Follow up of the Grade 1, 2, 3 and 4 injuries were performed under intensive care conditions.

Surgical exploration is of first priority in hemodynamically unstable patients and those with peritoneal irritation findings (11). In addition, explorative surgical treatment should be considered in the cases of suspected perforation and increased abdominal pain (12). In a study, empty organ perforation was reported by $0.3 \%$ in 227,972 patients with blunt abdominal trauma (13). In our study, intestinal perforation was found as $30 \%$ of the patients with failed NOM and $2.8 \%$ in all patients with liver injury due to blunt trauma. While in our patients empty organ injuries were seen in low-grade injuries, biliary peritonitis was found in high-grade liver traumas. CT is an inevitable technique in the arrangement of diagnosis and treatment in patients with blunt abdominal trauma. Pneumoperitoneum is the most helpful techniques for clinicians to show retroperitoneal bleedings and the amount of intraperitoneal hemorrhage $(14,15,19)$. It has been recommended that $\mathrm{CT}$ is not necessary during routine follow-up, but CT control should be performed in the cases of jaundice, unexplained sudden decreases in hemoglobin values, elevated transaminases and constantly increasing abdominal pain $(17,18)$. In the literature, some authors have reported that they use CT in the follow-up of patients who received NOM, while the others stated that they perform CT control in Grade 3 and higher injuries (19). There are studies reporting that repeated CT examinations do not change treatment or studies reporting that these examination must be definitely performed for the detection of pseudoaneurysms in Grade 2 and higher traumas (20, 21). In our study, CT was used in the first diagnosis of the patients following FAST. Routine imaging was not performed in our patients before the discharge. We recommend to perform CT controls in patients with a significant decrease in hemoglobin-hematocrit values despite adequate resuscitation, unexplained abdominal pain, and those with GIS bleeding such as melena, hemobilia, and hematemesis detected. Biochemically elevated bilirubin values despite not 
observing decrease in hemoglobin values within the first 24 hours of the trauma in patients who underwent laparotomy with failed NOM and biliary peritonitis suggests biliary leak.

Need for resuscitation in order to maintain hemodynamic stability, high injury grade, multiple solid organ injury, large hemoperitoneum and contrast leak on CT have been reported as the factors increasing NOM failure. It has been stated that these findings may lead to need for angioembolization in addition to NOM or laparotomy (22). Furthermore, the success rate has been reported as high in Grades 4-5 injuries $(4,23,24)$. In our patients, the causes of the development of complications and NOM failure were found as high grades of injury and the need for continuous resuscitation. Multiple solid organ injuries were more common in patients with failed NOM. Among hemodynamically unstable patients, those with Grade 4 trauma should be more carefully followed up in terms of complications.

Bilioma, liver abscess, hemobilia, biliary peritonitis and hemoperitoneum may be seen in patients with liver trauma receiving NOM (25-27). The rate of complications has been reported as $1 \%$ in Grade 3 injuries, $21 \%$ in Grade 4 injuries, and $63 \%$ in Grade 5 injuries (27-29). Complications of biliary tract injuries are manifested later in clinical follow-up, and biliary peritonitis, bilioma, and sepsis have reported in 3.2\% of all liver injuries $(25,27)$. It has been recommended that ERCP+stent+percutaneous drainage can be performed in high flow rate peripheral localization, and laparoscopic intra-abdominal irrigation can be carried out in order to decrease biliary sepsis if biliary leak is controlled after ERCP+stent+percutaneous drainage (30-32). It has been reported that intrahepatic abscess develops by $4 \%$ and causes mortality by $10 \%$ in all liver traumas $(29,33)$. In our study, complications such as bilioma and liver abscess developed in 2 patients were treated with percutaneous drainage, ERCP and stenting. Consistently with the literature, injury grades were found as Grade 3 and 4 in the complicated patients.

There is a severe thorax trauma in $50 \%$ of patients with multiple trauma (1). In our study, the most finding in addition to liver trauma was found as thorax trauma in the patients who received NOM. In a series of 1642 patients by Ozcelik et al. on thorax trauma, pneumothorax was reported as $41.6 \%$ (34). Rib fracture is seen in $21 \%$ of blunt thorax trauma cases (35). In our study also pneumothorax and rib fractures were most commonly seen events among thorax traumas $(p>0.05)$. Thorax traumas were seen in $5(50 \%)$ patients who underwent surgery and in 53 $(56 \%)$ patients who received conservative treatment. No significant difference was observed between the two groups $(p=0.475)$.

\section{CONCLUSION}

In conclusion; patients with blunt abdominal trauma are most commonly accompanied by thorax trauma. NOM is a current approach in the treatment of blunt abdominal trauma. NOM should be performed in the centers with facility of radiologic procedures, and intensive care conditions. The development of complications increases as injury grade increases. Control imaging examinations should be performed in order to determine complications timely in the cases of NOM carried out in Grade 4 injuries.

Conflict of interest: Authors declare that there is no conflict of interest between the authors of the article.

Financial conflict of interest: Authors declare that they did not receive any financial support in this study.

Address correspondence to: Mehmet Aykut Yildirim, Necmettin Erbakan University, Meram Faculty of Medicine, Department of General Surgery, Konya, Turkey

Telephone: 903322236148

e-mail:drmayildirim@hotmail.com

\section{REFERENCES}

1. Cohn SM. Pulmonary contusion: Review of the clinical entity. J Trauma 1997;42:973.

2. Kozar RA, Moore FA, Moore EE, et al. Western trauma association critical decisions in trauma: Nonoperative management of adult blunt hepatic trauma. J Trauma 2009;67:1144-9.

3. Afifi I, Abayazeed S, El-Menyar A. et al. Blunt liver trauma: A descriptive analysis from a level I trauma center. BMC Surg 2018:19;18(1):42.

4. Sabe AA, Claridge JA, Rosenblum DI, et al. The effects of splenic artery embolization on non-operative management of blunt splenic injury: A 16-year experience. J Trauma 2009;67:565-72.

5. Malhotra AK, Fabian TC, Croce MA, et al. Blunt hepatic injury: A paradigm shift from operative to nonoperative management in the 1990s. Ann Surg 231:804;2000

6. Stassen NA, Bhullar I, Cheng JD, et al. Nonoperative management of blunt hepatic injury: An Eastern Association for the Surgery of Trauma practice management guideline. J Trauma Acute Care Surg 2012;73(5 Suppl 4):288-93.

7. Carrillo EH, Spain DA, Wohltmann CD, et al. Interventional techniques are useful adjuncts in non-operative management of hepatic injuries.J Trauma 1999;46:619-24.

8. Becker CD, Mentha G, Terrier F. Blunt abdominal trauma in adults: Role of $\mathrm{CT}$ in the diagnosis and management of visceral injuries. Part 1: Liver and spleen. Eur Radiol 
1998;8:553-62.

9. Richardson JD, Franklin GA, Lukan JK, et al. Evolution in the management of hepatic trauma: A 25 year perspective. Ann Surg 2000; 232:324-330

10. Green CS, Bulger EM, Kwan SW. Outcomes and complications of angioembolization for hepatic trauma: A systematic review of the literature. J Trauma Acute Care Surg 2016; 80:529.

11. Prichayudh S, Sirinawin C, Sriussadaporn S, et al. Management of liver injuries: Predictors for the need of operation and damage control surgery. Injury 2014;45:13737.

12. Nance ML, Peden GW, Shapiro MB, et al. Solid organ injury predicts major hollow viscous injury in blunt abdominal trauma. J Trauma1997;43:618-25.

13. Fakhry SM, Watts DD, Luchette FA. Current diagnostic approaches lack sensitivity in the diagnosis of perforated blunt small bowel injury: Analysis from 275,557 trauma admissions from the EAST multi-institutional $\mathrm{HVI}$ trial. J Trauma 2003;54:295-306.

14. Fang JF, Wong YC, Lin BC, et al. The CT risk factors for the need of operative treatment in initially stable patients after blunt hepatic trauma. J Trauma 2006;61:547-54.

15. Fang JF, Chen RJ, Wong YC, et al. Classification and treatment of pooling of contrast material on computed tomographic scan of blunt hepatic trauma. J Trauma 2000;49:1083-8.

16. Wurmb TE, Fruhwald P, Hopfner W, et al. Whole-body multislice computed tomography as the first line diagnostic tool in patients with multiple injuries: The focus on time. $J$ Trauma 2009;66:658-65.

17. Tan KK, Bang SL, Vijayan A, et al. Hepatic enzymes have a role in the diagnosis of hepatic injury after blunt abdominal trauma. Injury 2009;40:978-83.

18. Lee WC, Kuo LC, Cheng YC, et al. Combination of white blood cell count with liver enzymes in the diagnosis of blunt liver laceration. Am J Emerg Med 2010;28:1024-9.

19. Fata P, Robinson L, Fakhry SM. Survey of EAST member practices in blunt splenic injury: A description of current trends and opportunities for improvement. J Trauma 2005;59(4):836-41.

20. Shapiro MJ, Krausz C, Durham RM, et al. Overuse of splenic scoring and computed tomographic scans. J Trauma 1999;47:651-8.

21. Weinberg JA, Manotti LJ, Croce MA, et al. The utility of serial computed tomography of blunt splenic injury: Still worth a second look? J Trauma 2007;62:1143-8

22. Yanar H, Ertekin C, Taviloglu K, et al. Nonoperative treatment of multiple intra-abdominal solid organ injury after blunt abdominal trauma. J Trauma 2008;64(4):943-8.

23. Fu CY, Wu SC, Chen RJ, et al. Evaluation of need for operative intervention in blunt splenic injury: Intraperitoneal contrast extravasation has an increased probability of requiring operative intervention. World J Surg 2010;34: 274551

24. Letoublon C, Chen Y, Arvieux C, et al. Delayed celiotomy or laparoscopy as part of the non-operative management of blunt hepatic trauma. World JSurg 2008;32:1189-93

25. Christmas AB, Wilson AK, Manning B, et al. Selective management of blunt hepatic injuries including non-operative management is a safe and effective strategy. Surgery 2005;138:606-11
26. Velmahos GC, Toutouzas K, Radin R, et al. Non-operative treatment of blunt injury to solid abdominal organs: A prospective study. Arch Surg 2003;138:844-51.

27. Miller PR, Croce MA, Bee TK, et al. Associated injuries in blunt solid organ trauma: Implications for missed injury in non-operative management. J Trauma 2002;53:238-44.

28. Kozar RA, Moore FA, Cothren CC, et al. Risk factors for hepatic morbidity following non-operative management: Multicenter study. Arch Surg 2006;141:451-9.

29. Green CS, Bulger EM, Kwan SW. Outcomes and complications of angioembolization for hepatic trauma: A systematic review of the literature. J Trauma Acute Care Surg 2016; 80:529.

30. Tan KK, Bang SL, Vijayan A, et al. Hepatic enzymes have a role in the diagnosis of hepatic injury after blunt abdominal trauma. Injury 2009;40:978-83.

31 Letoublon C, Chen Y, Arvieux C, et al. Delayed celiotomy or laparoscopy as part of the non-operative management of blunt hepatic trauma. World J Surg 2008;32:1189-93.

32. Carrillo EH, Reed DN Jr, Gordon L, et al. Delayed laparoscopy facilitates the management of biliary peritonitis in patients with complex liver injuries. Surg Endosc 2001;15:319-22.

33. Claridge JA, Young JS. Asuccessful multimodality strategy for management of liver injuries. Am Surg 2000;66:920-6.

34. Ozcelik C, Balcı AE, Eren S, et al. Toraks travmaları (10 yıllık deneyim). Ulusal Travma Dergisi 2000;6:44-9.

35. Marasco S, Lee G, Summerhayes R, et al. Quality of life after major trauma with multiple rib fractures. Injury 2015;46(1):615. 